\title{
Factors Affecting Mobile Banking Adoption: An Empirical Study in Gwalior Region
}

Pooja Jain. Jiwaji University, Gwalior, Madhya Pradesh. India pooja.jain@prestigegwl.org

Gaurav Agarwal. ABV-IIITM, Gwalior, Madhya Pradesh. India drgauravagrawal@gmail.com

\begin{abstract}
The aim of this study is to examine the factors which influence customers to adopt mobile banking. Going through the previous literature, four determinant factors have been identified. Individual variable is evaluated using a 5-point Likert-scale. Self-administered quantitative questionnaires were distributed, targeting the respondents in the Gwalior region which falls in central Indian state of Madhya Pradesh, using the primary data collection method. A quantitative research technique was utilized for this exploration. A pilot investigation of 20 respondents was led to confirm the reliability of the questionnaire. Data was analysed using regression tests. The outcomes of this investigation brought the conclusion that perceived utility, perceived convenience, and perceived trust have a positive impact on the behavioural intention to adopt mobile banking whereas perceived financial costs were found to be insignificant. The paper concludes with a discussion of the exploration results and draws out a few implications for future research.
\end{abstract}

Keywords: behavioural intention, mobile banking, digitalization 


\section{INTRODUCTION}

Digital channels like mobile banking are presumed to offer wider coverage and extra price-efficient services to the unbanked population of our nation. Traditional banking is not expensive however it lacks financial inclusion which is disadvantageous to the Digital India scheme of the Government of India. Financial inclusion provides a wide variety and diversification of monetary services for the entire population in maximum value-effective manner. Currently, as low as $47 \%$ of population in India has unique banking offers. Financial inclusion cannot be achieved until the entire population receives a wide variety of banking offerings. Furthermore, simply providing broad forms of banking services, with a large style of technical services, would not be sufficient to realize the purpose of the Government of India to create a "Digital India". The objective of the "Digital India" program is to digitally hand over every citizen of India and fulfil the post of an authority in Information Technology (IT) for the advancement of health, education system and banking offerings (as envisaged with the aid of the Government of India (GoI) in their Vision and Vision Area, digital India vision record, 2019). The goal behind branding the country as "Digital India" is to gain a leadership role for India in the field of IT. Once India is in the competitive position, it is proposed that its benefits should be used to offer higher health, education and banking.

Focusing on banking offerings, it is very important to understand that every citizen of India can explore a wide variety of such offerings in a cost-effective manner using technically superior services that can be powerful in terms of value. One such service is mobile banking services. Ensuring the adoption of such services by all citizens of India is extra challenging. It will be important to make sure that adoption is taken as a primary step to know customer's willingness to accept technologically progressive services like mobile banking. Taking such a step, in the process of primary studies, may provide special insight into the disinvestment of Indians to adopt mobile banking (if such sentiments are present). Policy makers must then work to overcome any obstacle to such ploughing of profit. This will ensure the most effective level of acceptance of technologically superior networks, and an understanding of the Government of India to act as presenter of reaching a leadership position in Information Technology under the banner of "Digital India". 
Taking into consideration the above mission, it is very important to understand the attitude of Indian customers towards accepting mobile banking as well as technically superior services, especially for those who have not yet adopted it. This will illustrate the ability of mobile banking as a network to ride financial inclusion, based on the intention of consumers to introduce mobile banking. Expressive financial inclusion cannot occur until every Indian has an access to a wide variety of financial services. Similarly, unless every Indian accepts the digital network to have an access to a huge variety of financial and non-financial services, the Indian Government's action to create "Digital India" cannot be realized.

Communication and information systems have changed the world, like the Web and Wi-Fi technologies. In particular, the mobile sector is rising tremendously in both developed and developing countries. India has 936 million Wi-Fi subscribers, as per the data released by India's Telecom Regulatory Authority (Performance Indicators Reports, 2018). Additionally, by the end of 2018, the number of Internet users in India is expected to exceed 300 million (Sankaran, 2018).

Banks now offer a variety of facilities via mobile systems to meet the expectations of the customers. Announced in India in the late 1990s and early 2000s, mobile banking is well defined as "a network through which the client connects with a financial institution via a handheld device such as a mobile phone or personal digital assistant" (Barnes et al., 2003). In developing nations, where consumers mainly access the internet via mobile phones, it has a considerable potential. The main advantage of mobile banking is that it is possible to conduct banking transactions anytime, anywhere (Laukkanen, 2007). Without a visit to a traditional bank, customers can view their account balance, transfer funds between accounts, and make digital bill payments as well. Thus, mobile banking decreases the physical separation between both the financial institution and the consumer and helps clients attain financial inclusion. There are 18.7 bank branches per 100,000 adults in urban parts of India, whereas in semi-urban and rural parts this proportion is only 7.8. The volume of ATMs in India is 205.151, indicating that India has a good potential to get attractive market financial services from mobile banking (RBI, 2016). In rural parts of India, only 5\% of the adult population enters a commercial bank branch and only $40 \%$ have bank accounts (India Brand 
Equity Foundation Annual Report, 2016). In addition, internet penetration is far less, particularly in comparison to mobile penetration in rural locations. In rural locations, where bank branches are sparse, it could be simpler to give financial services via mobile phones than via any other delivery network. Despite mobile banking advantages, in India, consumers rarely practice these banking services (BCG Report, 2016). The rise in the practice of non-bank firms' mobile wallets, such as Paytm, also competes with bank. As per the study, $21 \%$ of the $32 \%$ of online banking consumers use a non-bank mobile wallet instead of using the mobile banking services provided by their own banks. India is currently in a demonetisation trend, with India's government and India's Reserve Bank (the banking regulatory authority) progressively cheering cashless transactions. Mobile banking also performs a crucial role in cultural situations and economic issues (Bankole et al., 2011); (Amin and Ramayah, 2010). The results of previous research in different regions of the globe can therefore be used as a manual, but they do not clarify the existing financial environment in India alone. Certainly, the acceptance of mobile banking in India has been inspected by partial research studies (Kumar et al., 2017), representing a necessity for more study to know persuaders and inhibitors of m-banking acceptance in India. To fill the gap among high digital wallet stimulation and minimal mobile banking adoption, we need to create a system that gauges the factors that led to mobile banking being accepted. The literature marks out that, if examined in various economic, cultural and political configurations, the same components or hypotheses will produce different outcomes (Afshan and Sharif, 2016).

\section{LITERATURE REVIEW}

Past empirical, mobile banking researches also propounded various theories to examine adoption intent, demonstrating varying results. This makes it hard for financiers and researchers to classify the main drivers and inhibitors for implementation of mobile banking. Previous research has found that the achievement of new delivery networks made possible by technology, like mobile banking, largely depends on consumer adoption (Hanafizadeh et al., 2014). Therefore, it is important to examine the factors that influence customers to adopt mobile banking. 


\subsection{Perceived usefulness}

Perceived usefulness (PU) is defined as "the extent to which a person knows that using a particular method will improve their ability to do the job" (Venkatesh et al., 2003). In the previous fiction, PU was noted as one of Behaviour Intention (BI)'s many influential drivers for adopting m-banking (Akturan and Tezcan, 2012); (Hanafizadeh et al., 2014); (Luarn and Lin, 2005). Wessels and Drennan (2010) experimentally endorsed perceived usefulness (PU) as a core predictor of behaviour intention (BI) adopting m-banking by Aussie consumers, (Gu et al., 2009) also experimentally endorsed the part of PU in contributing to the ability of users to exercise m-banking. Hanafizadeh et al. (2014) recently endorsed PU's vital role in inspiring Iranian clients to embrace m-banking. The role viewed that implications can significantly affect the real use behaviour as per the PC usage system (Tan and Teo, 2000). Alalwan et al. (2016) endorsed this assertion by verifying a strong bond with performance requirements.

Effectiveness is an important precedent for the sole aim of individuals to embrace new tech (Lada et al., 2009). Presumed utility "is the extent to which an ordinary person thinks his employment status will be enhanced through the use of a system" (Venkatesh et al., 2003). In the past research, empirical proof endorses the good relationship in both presumed utility and purpose utilised mobile banking. For instance, (Wang et al., 2003) claims that customers in Taiwanese financial services carefully consider the advantages and perks of online banking services while taking decisions about implementation. Likewise, (Akturan and Tezcan, 2012) discovered the intelligent characteristics and fantastic mobility of such payment services which push the propagation of mobile banking in Turkey. The more users portray comparative benefits of mobile banking as being, the more probably they are to conduct financial transactions through smart devices (Koenig-Lewis et al., 2010). Banking customers are ready to use mobile banking if they're really convinced that their advantages are higher than those of other banking delivery networks (Arif et al., 2016). Al-Sharafi et al. (2017) observed that perceived usefulness positively impacts the attitude towards mobile banking adoption. The study found that creation of positive attitude in the midst of customers for mobile banking is built when technology is accepted first. Attitude is influenced by perceived usefulness and students are familiar with the technology devices and it is helpful to use it for learning (Shokouhyar et al., 
2017). It also has a significant impact on trust (Al-Sharafi et al., 2017). Priya et al. (2018b), determined the components impacting adoption of mobile banking among young Indian buyers. The discoveries of the examination propose that perceived usefulness is a solid determinant of user's satisfaction and behaviour intention for utilising mobile banking services. The US was found to intervene, in part, the connection among perceived usefulness and behaviour intention to utilise the mobile banking service. Priya et al. (2018a) discoveries of the investigation propose that perceived usefulness is a firm determinant of user's satisfaction and intention behaviour to make use of mobile banking services. User's satisfaction was mostly found to intercede the connection between perceived usefulness and intention behaviour. Thaker et al., (2019) revealed that perceived usefulness is found to be an important factor influencing customer's attraction towards Islamic mobile banking services. Users want a simple, an easy, and a fast performing process for banking transactions.

\subsection{Perceived convenience}

Given the cost-benefit structure, ongoing research indicates that convenience is really a major advantage of embracing mobile banking technologies, while safety is the key price. For several high-tech products, comfort is a vital benefit (Laukkanen and Pasanen, 2008). With respect to mobile banking, users can gain immense convenience and effectiveness from such a network. Customers can install and upload information and make mobile phone money transfers without travelling to the bank. In internet banking study, (Eastin, 2002) proposed that convenience could be used as a relevant indicator of the acceptance of internet banking technologies by consumers. In addition, (Pura, 2005) also pointed out that in highly target-oriented mobile services, convenience has a powerful impact on the intent to accept the systems. This research agrees with previous findings and assumes a similar consequence of convenience on m-banking service acceptance.

\subsection{Perceived financial cost}

During our qualitative presentations with them, as pointed out earlier, many customers revealed that concern of financial costs can affect their psychological intent to use mobile banking. Perceived financial costs (PFC) are described as the degree in which a person thinks that using mobile banking will cost a lot of money. However, most common attractions of Information system (IS) approval 
research are economic incentive and outcomes. Wireless system usually requires significant payments such as exposure, monthly fee, service and trading costs, and also devices to use mobile services, unlike wired internet telecommunications. Therefore, perceived costs have been advocated in this research, and determined as the degree by which a customer claims that the extra expenses will be good enough to warrant using a Mobile financial services (MFS). Yen et al. (2010) discovered that perceived cost plays a key role in customer adoption choices in the case of mobile commerce. They confirmed that perceived cost had a negative impact on the specific intent of behaviour. Likewise, other experiments have replaced perceived costs with a comparable theoretical structure, ' perceived financial resources' (Luarn and Lin, 2005). These researches also experimentally revealed that perceived financial cost would have an adverse effect on cellular service's behavioral intent.

\subsection{Perceived trust}

Initial confidence represents "an individual's willingness to take risks to reach the need without previous experience or reliable and relevant details (Kim et al., 2009)". In relational and company interaction, it has been widely discussed (Kim et al., 2009). Trust is considered to be connected to different service industries and to contribute significantly to its adoption (Chen, 2013). Evaluating the position of original faith in technology and innovation, ITM has obtained distinct exposure in the literature on digital trade due to high instability and domain - related risks. Many analysts acknowledged the role of final confidence in forecasting technology adoption. Initial belief is affected by systemic certainty among the systemic or environmental powers (Kim et al., 2009) and organizational familiarity (Gefen et al., 2003). In particular, branchless financial sector depends on the indirect relationship between the concerned parties. There is no existence of information- focused belief in such conditions that has generally emerged from social interaction (Mcknight et al., 2002). It is, therefore, thought that final trust, based on specific view points of the person, will be essential in embracing the use of technology. In instances where trust emerges without previous experiences, it is asserted that the customer has a dependable association with the provider because of the powerlessness of his occasions utilizing a specific framework (Kim et al., 2009). In overview, the scope of trust can differ as it depends on existing relationships, perspectives, stages of growth and signs (Rousseau et al., 1998). 
Trust is a psychological expectation that a trusted party will not behave opportunistically (Bunduchi, 2005); (Rousseau et al., 1998). Post-utilisation awareness plays a fundamental role in building user's perceptions in perceived usefulness, perceived security, and privacy in using mobile banking services. It also builds up consumer satisfaction level and trust level. The study also reveals that perceived security and privacy ,together, impacts trust, however not on users' satisfaction (Susanto et al., 2016). Farah et al. (2018) determined the important components that help to clarify the intention of customers and conduct towards the adoption of mobile banking. A unified theory of acceptance is considered for study. Confidence and risk are likewise included goals. The study found that trust has a great influence on behavioural intention. Shareef et al. (2018) believed that if consumers are confident about security in this service delivery channel at the transaction stage, they will be more than willing to adopt the service. For consumers, the results reveal that security is the biggest predictor of trust in this service phase. The study found that trust on behavioural intention is negligible. Zhou (2018) revealed that trust has a less noteworthy effect on the uses of mobile banking against customers. Study recommended that when users have built up trust in mobile banking, they will be prepared to move in the system. Infections, for example, worms and Trojan ponies can likewise taint mobile devices. These issues raise worries over users' mobile banking security. They may need to assemble enough certainty to decrease apparent hazard and move to mobile banking.

\subsection{Hypothesis}

H1: There is a significant impact of perceived usefulness on behaviour intention towards mobile banking adoption.

H2: There is a significant impact of perceived convenience on behaviour intention towards mobile banking adoption.

H3: There is a significant impact of perceived financial cost on behaviour intention towards mobile banking adoption.

H4: There is a significant impact of perceived trust on behaviour intention towards mobile banking adoption. 


\section{RESEARCH METHODOLOGY}

A quantitative research method has been adopted for this research. Selfadministered quantitative questionnaires were distributed in Gwalior region, India. Various factors like perceived usefulness (PU), perceived convenience (PC), perceived trust (PT), perceived financial cost (PFC) and behaviour intention (BI) have been identified through previous literature and adopted for this study. A pilot study of 20 respondents was conducted in the month of March, 2019 to ensure reliability of the questionnaire. In between March, 2019 to April, 2019, the data from 292 students using mobile banking has been collected. Due to time constraints, this study used regression tests only. The data collected from the questionnaire were analysed using statistical analysis to examine the factors influencing behaviour intention towards adopting mobile banking.

\begin{tabular}{|l|l|l|l|l|}
\hline Variables & $\begin{array}{l}\text { Cronbach's } \\
\text { Alpha }\end{array}$ & $\begin{array}{l}\text { Comparable } \\
\text { value }\end{array}$ & Explanation & $\begin{array}{l}\text { Number of } \\
\text { Statements }\end{array}$ \\
\hline $\begin{array}{l}\text { Perceived } \\
\text { Usefulness }\end{array}$ & .681 & .6 to .7 & $\begin{array}{l}\text { Reliable and } \\
\text { consistent }\end{array}$ & $\mathbf{4}$ \\
\hline $\begin{array}{l}\text { Perceived } \\
\text { Convenience }\end{array}$ & .821 & $\mathbf{. 6 ~ t o . 7}$ & $\begin{array}{l}\text { Reliable and } \\
\text { consistent }\end{array}$ & $\mathbf{4}$ \\
\hline $\begin{array}{l}\text { Perceived } \\
\text { Financial Cost }\end{array}$ & .885 & $\mathbf{. 6}$ to .7 & $\begin{array}{l}\text { Reliable and } \\
\text { consistent }\end{array}$ & $\mathbf{4}$ \\
\hline $\begin{array}{l}\text { Perceived Trust } \\
\text { Reliable } \\
\text { consistent }\end{array}$ & .878 & $\mathbf{. 6}$ to .7 and & $\mathbf{6}$ \\
\hline $\begin{array}{l}\text { Behavioural } \\
\text { Intentions }\end{array}$ & .867 & $\mathbf{. 6}$ to .7 & $\begin{array}{l}\text { Reliable } \\
\text { consistent }\end{array}$ & $\mathbf{4}$ \\
\hline
\end{tabular}

Table 1. Reliability

\subsection{Interpretation of reliability}

It is quite important to examine the characteristics of measuring scales and the aspects that formulate the scales. Utilisation of SPSS software has been made in order to assure that the factors in the model are accurate. Cronbach's Alpha Index is the most generally used reliability test. This contains analysis as a coefficient of correlation and ranges from 0 to 1 . Apart from this, utilising the Cronbach's Alpha Index can decide if the survey is dependable and the information can be used for further investigation. Further investigation can possibly be done if the Cronbach's 
Alpha Index test is passed. The acknowledgment dimension of Cronbach Alpha Index is ought to be between 0.6 and 0.7. Table 1 demonstrates the outcome of reliability statistics which is Perceived Usefulness (0.681), Perceived Convenience (0.821), Perceived Financial Cost (0.885), Perceived Trust (0.878), Behavioural Intentions (0.867) and it is exceedingly reliable. Therefore, these tools can be used for future studies too on the same variable and are more likely to generate consistent results.

\section{REGRESSION ANALYSIS}

Tables 2, 3, 4 and 5 provide the details of the model summary and the results of the regression analysis. Afterwards, the interpretation of the regression analysis results is being provided. The regression results comprise three tables i.e. model summary, ANOVA and coefficient. 'Model summary' table, provides information about the regression line's ability to account for the total variation in the dependent variable. The ANOVA table determines the means between the groups and also determines whether any of those means are significantly different from each other. Coefficient table indicates the direction of the relationship between a predictor variable and the response variable.

\begin{tabular}{|l|l|l|l|l|l|}
\hline Model & $\mathrm{R}$ & R Square & $\begin{array}{l}\text { Adjusted R } \\
\text { Square }\end{array}$ & $\begin{array}{l}\text { Std. Error of } \\
\text { the Estimate }\end{array}$ & $\begin{array}{l}\text { Durbin- } \\
\text { Watson }\end{array}$ \\
\hline 1 & $.709^{\mathrm{a}}$ & .503 & .496 & 2.32957 & 1.748 \\
\hline
\end{tabular}

a) Predictors: (Constant), PT, PFC, PU, PC; b) Dependent Variable: BI

Table 2. Model Summary

\begin{tabular}{|c|c|c|c|c|c|c|}
\hline \multicolumn{2}{|c|}{ Model } & Sum of & $D f$ & Moาn Caun & $\Gamma$ & Sir \\
\hline 1 & Regression & 1578.104 & 4 & 394.526 & 72.698 & $.000 \mathrm{a}$ \\
\hline & Residual & 1557.526 & 287 & 5.427 & & \\
\hline & Total & 3135.630 & 291 & & & \\
\hline
\end{tabular}

b) Predictors: (Constant), PT, PFC, PU, PC; b) Dependent Variable: BI

Table 3. ANOVA ${ }^{\mathrm{b}}$ 


\begin{tabular}{|c|c|c|c|c|c|c|}
\hline \multicolumn{2}{|c|}{ Model } & \multicolumn{2}{|c|}{ Unstandardised Coefficients } & \multirow{3}{*}{$\begin{array}{l}\text { Standardised } \\
\text { Coefficients } \\
\text { Beta }\end{array}$} & \multirow{3}{*}{4.893} & \multirow{3}{*}{$\begin{array}{l}\text { Sig. } \\
.000\end{array}$} \\
\hline & & \multirow{2}{*}{$\begin{array}{l}\text { B } \\
4.155\end{array}$} & \multirow{2}{*}{$\begin{array}{l}\text { Std. Error } \\
.849\end{array}$} & & & \\
\hline 1 & (Constant) & & & & & \\
\hline & PU & 196 & .053 & .204 & 3.697 & .000 \\
\hline & PC & .226 & .062 & .230 & 3.661 & .000 \\
\hline & PFC & -.043 & .031 & -.059 & -1.392 & .165 \\
\hline & PT & .271 & .038 & .388 & 7.049 & .000 \\
\hline
\end{tabular}

a) Dependent variable: BI

Table 4. Coefficients ${ }^{\mathrm{a}}$

\begin{tabular}{|c|c|c|c|c|c|c|c|}
\hline $\begin{array}{l}\text { Criterion } \\
\text { (Dependent } \\
\text { Variable) }\end{array}$ & $\begin{array}{l}\text { Predictor } \\
\text { (Independent } \\
\text { Variable) }\end{array}$ & Hypothesis & $\begin{array}{l}\mathrm{R} \\
\text { Square }\end{array}$ & $\mathrm{t}$ & \multicolumn{2}{|c|}{$\begin{array}{l}\text { Statistic } \\
\text { Test } \\
\text { Sig. } \\
\text { Beta }\end{array}$} & Results \\
\hline \multirow{4}{*}{$\begin{array}{l}\text { Behavioral } \\
\text { intention } \\
\text { towards } \\
\text { mobile } \\
\text { banking } \\
\text { adoption }\end{array}$} & $\begin{array}{l}\text { Perceived } \\
\text { Usefulness }\end{array}$ & $\mathrm{H} 1$ & \multirow[t]{4}{*}{.503} & 3.697 & .000 & -204 & Supported \\
\hline & $\begin{array}{c}\text { Perceived } \\
\text { Convenience }\end{array}$ & $\mathrm{H} 2$ & & 3.661 & .000 & -203 & Supported \\
\hline & $\begin{array}{c}\text { Perceived } \\
\text { Financial Cost }\end{array}$ & H3 & & -1.392 & .165 & $\begin{array}{c}- \\
.059\end{array}$ & Rejected \\
\hline & $\begin{array}{l}\text { Perceived } \\
\text { Trust }\end{array}$ & $\mathrm{H} 4$ & & 7.049 & .000 & .388 & Supported \\
\hline
\end{tabular}

Table 5. The results of regression analysis

\subsection{Interpretation of regression analysis}

Regression analysis was applied between perceived usefulness, perceived convenience, perceived financial cost and perceived trustworthy as independent variables and for behaviour intention towards mobile banking adoption as a 
dependent variable. Value of $\mathrm{R}$ Square was found to be .503, therefore independent variables explain 50.3\% variance in dependent variable behaviour intention. Value of Durbin Watson was 1.748 which is within the range of 1.5-2.5. A separate Outlier test was performed to remove the present outliers for the respondents. The model used for regression has a good fit as indicated by F value 72.698 significant at .000 level indicating a high predictability of model.

In the line, the relationship between perceived usefulness as an independent variable and behaviour intention towards mobile banking adoption as a dependent variable is indicated by standardized coefficient Beta with a value of 0.204 . The importance of beta is tested using value for $\mathrm{t}$ (3.697) which is significant at $0 \%$ level of significance indicating considerable effect of perceived usefulness as an independent variable on behaviour intention as a dependent variable.

Similarly, the connection between perceived convenience as an independent variable and behaviour intention towards mobile banking adoption as a dependent variable is specified by standardized coefficient Beta with a value of 0.226 . The significance of beta is tested using value for $t$ (3.661) which is significant at $0 \%$ level of significance indicating major effect of perceived convenience as an independent variable on behaviour intention as a dependent variable.

In the same line, link between perceived financial cost as an independent variable and behaviour intention towards mobile banking adoption as a dependent variable is signified by standardized coefficient Beta with a value of -.059. The significance of beta is tested using value for $t(-1.392)$ which is not significant at $0 \%$ level of significance indicating that there is no noteworthy effect of perceived financial cost as an independent variable on behaviour intention as a dependent variable.

Likewise, study also indicated that behaviour intention as a dependent variable and perceived trust as an independent variable is indicated by standardized coefficient Beta with a value of .388. The significance of beta is verified using value for $t$ (7.049) which is significant at $0 \%$ level of significance indicating that there is a major effect of perceived trust as independent variable on behaviour intention as a dependent variable. 


\section{DISCUSSION}

The purpose of this paper is to identify the factors affecting mobile banking adoption. Data has been collected from 292 respondents using mobile banking. In the model summary, the value of $\mathrm{R}^{2}$ is .503 , which means that $50.3 \%$ of the total variance of behaviour intention towards mobile banking has been explained as a moderate association among the dependent and independent variables. Further, in the coefficient table, the significant value is .000. Here, H1 is supported revealing that perceived usefulness has a significant impact on mobile banking adoption. This finding is consistent with the previous studies like (Akturan and Tezcan, 2012); (Hanafizadeh et al., 2014); (Luarn et al., 2005); (Delone et al., 2003) which indicated that perceived usefulness has a cardinal and a positive influence on intention toward system use. This result indicates that if mobile banking is useful and beneficial, customers are likely to adopt mobile banking services. As customers realise mobile banking services to be useful, adoption will increase. Similarly, H2 is also supported with significant value of .000 and results reveal that perceived convenience has a significant impact on mobile banking adoption. This finding is similar to the previous studies like (Laukkanen and Cruz, 2009); (Eastin, 2002); (Pura, 2005). This result indicates that if mobile banking is convenient to use, customers are likely to adopt mobile banking services. Many customers think that the use of mobile banking makes our daily life convenient. Likewise, H4 is supported with significant value 0.000 which reveals that perceived trust has a significant and a positive impact on mobile banking adoption and shows people's trust on mobile banking. This will positively lead to an increase in the utility. But in the study, H3 is not supported with a significant value of .165 which shows that perceived financial cost has a negative impact on mobile banking adoption. People think that by adoption of mobile banking leads to an additional charge for the user.

\section{CONCLUSIONS}

This study contributes considerably to the literature on behaviour intention of mobile banking adoption. The study experienced factors influencing the adoption of mobile banking from young perspective respondents in the Gwalior region, which is located in the state of Madhya Pradesh, India. We tested the relationship between perceived usefulness, perceived convenience, perceived financial cost, perceived trust and behaviour intention to adopt mobile banking. The results 
indicated that perceived usefulness, perceived convenience, and perceived trust have a significant effect on behavioral intention, implying that consumers recognise that the use of mobile banking is helpful and convenient in conducting banking operations and have also assumed that mobile banking service is reliable. They also believe that mobile banking service providers keep all the banking information safe with their promises and commitments but consumers feel that using mobile banking contributes to high cost and charges of mobile banking services are expensive. Therefore, mobile banking is still not widely used by customers in India. Based on this result, banks will have to make an extra effort to ensure that they provide a mobile banking platform affordable. The results of this study provide good evidence for banks to further improve their working practices in current technology and to increase overall penetration of mobile banking

\subsection{Implications}

- This research used students for data collection. Hence, data collection from different types of users could be possible for better understanding towards adoption of mobile banking.

- The methodology of the research is only based on quantitative data; further study could be used for qualitative research. Case study or interview method can be adopted to acknowledge in-depth problem of customers towards adoption of mobile banking.

- This study deals with a city of Madhya Pradesh, and it can be carried forward to other areas and countries to attract comparisons.

- For future research, TAM, TPB and other models may be used.

- The exploration plan of the examination is cross-sectional in nature. Future examinations may investigate a longitudinal research configuration to give a superior comprehension of the interrelationships among variables.

- This investigation can activate banks and motivate them to employ necessary considerations while executing mobile banking.

- The findings and implications are derived from a specific age group -from 18 to 30 years old where maximum respondents are young. Therefore, future studies are needed to generalize our findings and should also include people from other age groups.

- There are a few impediments of the present examination. The example, size and field of study become clear boundaries. Thus, caution is needed in the 
interpretation of the outcomes and ends cannot be generalized. Future investigations are required to generalise our outcomes.

\section{REFERENCES}

AFSHAN, S.; SHARIF, A. (2016): "Acceptance of Mobile Banking Framework in Pakistan", Telematics and Informatics, vol. 33, n. 2: 370-387. https://doi.org/10.1016/j.tele.2015.09.005

AKTURAN, U.; TEZCAN, N. (2012): "Mobile Banking Adoption of the Youth Market: Perceptions and Intentions”, Marketing Intelligence and Planning, vol. 30, n. 4: 444-459. https://doi.org/10.1108/02634501211231928

AL-SHARAFI, M. A.; ARSHAH, R. A.; HERZALLAH, F. A. T.; ALAJMI, Q. (2017): "The Effect of Perceived Ease of Use and Usefulness on Customers Intention to Use Online Banking Services: The Mediating Role of Perceived Trust”, International Journal of Innovative Computing, vol. 7, n. 1. http://se.fsksm.utm.my/index.php/ijic/article/view/139/62

ALALWAN, A. A.; DWIVEDI, Y. K.; RANA, N. P. P.; WILLIAMS, M. D. (2016): "Consumer adoption of mobile banking in Jordan", Journal of Enterprise Information Management, vol. 29, n.1: 118-139. https://doi.org/10.1108/JEIM04-2015-0035

AMIN, H.; RAMAYAH, T. (2010): "SMS Banking: Explaining the Effects of Attitude, Social Norms and Perceived Security and Privacy”, The Electronic Journal of Information Systems in Developing Countries, vol. 41, n. 1: 1-15. https://doi.org/10.1002/j.1681-4835.2010.tb00291.x

ARIF, I.; AFSHAN, S.; SHARIF, A. (2016): "Resistance to Adopt Mobile Banking in a Developing Country: Evidence from Modified TAM", Journal of Finance \& Economic Research, vol. 1, n. 1: 25-42. https://doi.org/ 10.20547/jfer1601104

BANKOLE, F. O.; BANKOLE, O. O.; BROWN, I. (2011): “Mobile Banking Adoption in Nigeria", The Electronic Journal of Information Systems in Developing Countries, vol. 47, n. 1: 1-23. https://doi.org/10.1002/j.16814835.2011.tb00330.x

BARNES, S. J.; CORBITT, B. J.; CORBITT, B. (2003): "Mobile Banking: Concept and Potential”, International Journal of Electronic Commerce, the 
Journal of Electronic Commerce Research, X(Y), 0-000. https://doi.org/ 10.1504/IJMC.2003.003494

BOSTON CONSULTING GROUP (BCG) REPORT IN DIGITAL AND BEYOND NEW HORIZONS IN INDIAN BANKING. (2016): http://imagesrc.bcg.com/Images/FIBAC-Digital-Beyond-Aug-2016_tcm21-40617.pdf

BUNDUCHI, R. (2005): "Business relationships in internet based electronic markets: the role of goodwill trust and transaction costs", Information System Journal, vol. 15, n. 4: 321-341. https://doi.org/ 10.1111/j.1365-2575.2005. 00199.x

CHEN, C. S. (2013): "Perceived risk, Usage Frequency of Mobile Banking Services”, Managing Service Quality, vol. 23, n. 5: 410-436. https://doi.org/ 10.1108/MSQ-10-2012-0137

DELONE, W.H; MCLEAN, E. R. (2003): “The DeLone and McLean Model of Information System Success”, Journal of Management Information Systems, vol. 19, n. 4: 9-30. https://doi.org/10.1080/07421222.2003.11045748

DIGITAL INDIA VISION AND VISION AREA (2019): Digital India Programme. https://digitalindia.gov.in/content/vision-and-vision-areas

EASTIN, M. S. (2002): "Diffusion of E-commerce: An Analysis of the Adoption of Four E-commerce Activities”, Telematics and Informatics, vol. 19, n. 3: 251267. https://doi.org/10.1016/S0736-5853(01)00005-3

FARAH, M. F; HASNI, M. J. S.; ABBAS, A. K. (2018): "Mobile Banking Adoption: Empirical Evidence from the Banking Sector in Pakistan”, International Journal of Bank Marketing, vol. 36, n. 17: 1386-1413. https://doi.org/ 10.1108/IJBM-10-2017-0215

GEFEN, D.; KARAHANNA, E.; STRAUB, D. W. (2003): "Trust and TAM in Online Shopping: An Integrated Model”, MIS Quarterly, vol. 27, n. 1: 51. https://doi.org/10.2307/30036519

GU, J. C.; LEE, S. C.; SUH, Y. H. (2009): "Determinants of Behavioural Intention to Mobile Banking”, Expert Systems with Applications, vol. 36, n. 9: 11605-11616. https://doi.org/10.1016/j.eswa.2009.03.024

INDIA BRAND EQUITY FOUNDATION (IBEF) REPORT. (2016): https://www.ibef.org/annual-report.aspx 
HANAFIZADEH, P.; BEHBOUDI, M.; ABEDINI KOSHKSARAY, A.; JALILVAND SHIRKHANI TABAR, M. (2014): "Mobile-banking Adoption by Iranian Bank Clients”, Telematics and Informatics, vol. 31, n. 1: 62-78. https://doi.org/10.1016/j.tele.2012.11.001

HANAFIZADEH, P.; KEATING, B. W.; KHEDMATGOZAR, H. R. (2014): “A Systematic Review of Internet Banking Adoption”, Telematics and Informatics, vol. 31, n. 3: 492-510. https://doi.org/10.1016/J.TELE.2013.04.003

KIM, G.; SHIN, B.; LEE, H. G. (2009): “Understanding Dynamics Between Initial Trust and Usage Intentions of Mobile Banking”, Information Systems Journal, vol. 19, n. 3: 283-311. https://doi.org/10.1111/j.1365-2575.2007.00269.x

KOENIG-LEWIS, N.; PALMER, A.; MOLL, A. (2010): "Predicting Young Consumers' Take Up of Mobile Banking Services”, International Journal of Bank Marketing, vol. 28, n. 5: 410-432. https://doi.org/10.1108/02652321011064917

KUMAR, R.V.V.; LALL, A.; MANE, T. (2017): "Extending the TAM model: Intention of management students to use mobile banking: Evidence from India”, Global Business Review, vol. 18, n. 1: 238-249. http://doi.org/ 10.1177/0972150916666991

LADA, S.; TANAKINJAL, G.H.; AMIN, H. (2009): "Predicting Intention to Choose Halal Products using Theory of Reasoned Action”, International Journal of Islamic and Middle Eastern Finance and Management, vol. 2, n. 1: 66-76. https://doi.org/10.1108/17538390910946276

LAUKKANEN, T. (2007): "Internet vs Mobile Banking: Comparing Customer Value Perceptions”, Business Process Management Journal, vol. 13, n. 6: 788797. https://doi.org/10.1108/14637150710834550

LAUKKANEN, T.; CRUZ, P. (2009): “Comparing Consumer Resistance to Mobile Banking in Finland and Portugal”, Springer, Berlin, Heidelberg, 89-98. https://doi.org/10.1007/978-3-642-05197-5_6

LAUKKANEN, T.; PASANEN, M. (2008): "Mobile Banking Innovators and Early Adopters: How They Differ from Other Online Users?”, Journal of Financial Services Marketing, vol. 13, n. 2: 86-94. https://doi.org/ 10.1057/palgrave.fsm.4760077

LUARN, P.; LIN, H. H. (2005): “Toward an Understanding of the Behavioural Intention to Use Mobile Banking”, Computers in Human Behavior, vol. 21, n. 6: 873-891. https://doi.org/10.1016/j.chb.2004.03.003 
MCKNIGHT, D. H.; CHOUDHURY, V.; KACMAR, C. (2002): "Developing and Validating Trust Measures for e-Commerce: An Integrative Typology", Information Systems Research, vol. 13. https://pdfs. semanticscholar.org/ b611/576195d9d883f9191b63009eb9483830a1b3.pdf

THAKER, M. B. M. T; PITCHAY, A. B. A; THAKER, H. B. M. T; AMIN M. F. B. (2019): “Factors Influencing Consumers' Adoption of Islamic Mobile Banking Services in Malaysia”, Journal of Islamic Marketing, JIMA-04-2018-0065. https://doi.org/10.1108/JIMA-04-2018-0065

PERFORMANCE INDICATORS REPORTS | TELECOM REGULATORY AUTHORITY OF INDIA. (N.D.). (2018): https://main.trai.gov.in/releasepublication/reports/performance-indicators-reports

PRIYA, R.; GANDHI, A. V.; SHAIKH; A. (2018a): “Mobile Banking: Consumer Perception towards Adoption”, Benchmarking: An International Journal, vol. 25, n. 12: 743-762. https://doi.org/10.1108/BIJ-01-2016-0009

PRIYA, R.; GANDHI, A. V.; SHAIKH; A. (2018b): “Mobile Banking Adoption in an emerging Economy”, Benchmarking: An International Journal, vol. 25, n. 2: 743-762. https://doi.org/10.1108/BIJ-01-2016-0009

PURA, M. (2005): “Linking Perceived Value and Loyalty in Location Based Mobile Services”, Managing Service Quality: An International Journal, vol. 15, n. 6, 509-538. https://doi.org/10.1108/09604520510634005

RESERVE BANK OF INDIA-REPORT. (2016): www.rbi.org.in/scripts/ PublicationReportDetails.aspx?ID=923

ROUSSEAU, D. M.; SITKIN, S. B.; BURT, R. S.; CAMERER, C. (1998): “Not So Different After All: A Cross-Discipline View of Trust", Academy of Management Review, vol.23, n. 3: 393-404. https://doi.org/10.5465/ amr.1998.926617

SANKARAN, S. (2018): Indian Mutual Funds Handbook. Orient Paperbacks, Vision Books Pvt. Ltd., New Delhi, India

SHAREEF, M. A.; BAABDULLAH, A.; DUTTA, S.; KUMAR, V.; DWIVEDI, Y. K. (2018): “Consumer Adoption of Mobile Banking Services: An Empirical Examination of Factors According to Adoption Stages", Journal of Retailing and Consumer Services, vol. 43: 54-67. https://doi.org/10.1016/J.JRETCONSER. 2018.03.003 
SHOKOUHYAR, S.; SAMADI, F.; TAVALLAEE, R. (2017): “The combined theory of Planned Behaviour and Technology Acceptance Model of Mobile Learning at Tehran Universities”, International Journal of Mobile Learning and Organisation, vol. 11, n. 2:176. https://doi.org/10.1504/IJMLO.2017.10005262

SUSANTO, A.; CHANG, Y.; HA, Y. (2016): "Determinants of Continuance Intention to Use the Smartphone Banking Services”, Industrial Management \& Data Systems, vol. 116, n. 3: 508-525. https://doi.org/10.1108/IMDS-05-20150195

TAN, M.; TEO, T. S. H. (2000): "Factors Influencing the Adoption of Internet Banking”, Journal of the Association for Information Systems, vol. 1. http://130.18.86.27/faculty/warkentin/SecurityPapers/Leigh/ZafarClark2009Other References/TanTeo2000_JAIS1_FactorsInfluencingInternetBankingAdoption.pdf

VENKATESH, V.; MORRIS, M. G.; DAVIS, G. B.; DAVIS, F. D. (2003): “User Acceptance of Information Technology: Toward a Unified View”, MIS Quarterly, vol. 27, n. 3: 425. https://doi.org/10.2307/30036540

WANG, Y.; WANG, Y.; LIN, H.; TANG, T. (2003): "Determinants of User Acceptance of Internet Banking: An Empirical Study", International Journal of Service Industry Management, vol. 14, n. 5: 501-519. https://doi.org/ 10.1108/09564230310500192

WESSELS, L.; DRENNAN, J. (2010): “An Investigation of Consumer Acceptance of M-banking”, International Journal of Bank Marketing, vol. 28, n. 7: 547-568. https://doi.org/10.1108/02652321011085194

YEN, D. C.; WU, C. S.; CHENG, F. F.; HUANG, Y. W. (2010): “Determinants of Users' Intention to Adopt Wireless Technology: An Empirical Study by Integrating TTF with TAM”, Computers in Human Behavior, vol. 26, n. 5: 906915. https://doi.org/10.1016/j.chb.2010.02.005

ZHOU, T. (2018): “Examining users' switch from online banking to mobile banking”, International Journal of Networking and Virtual Organisations, vol. 18, n. 1: 51. https://doi.org/10.1504/IJNVO.2018.090675 
Appendix A

\section{QUESTIONNAIRE}

Dear Respondent,

This is a survey-based study regarding behaviour intention of customers towards mobile banking. Please take your time to fill up this questionnaire as it will help us to identify the various indices that shows the adoption behaviour of the customers. The questionnaire is divided into sections related to perceived usefulness, perceived convenience, perceived financial cost, perceived trust, behaviour intention of customers and demographic details. I have taken 5 point Likert scale whereas $\mathbf{5}$ is Strongly agree and $\mathbf{1}$ is Strongly disagree. We assure that all data gathered from you will be kept at the highest level of confidentiality. Thanks for your time and support.

\begin{tabular}{|l|l|l|}
\hline \multirow{2}{*}{ Demographics } & Categories & $\begin{array}{l}\text { Mark right when } \\
\text { applicable }\end{array}$ \\
\hline \multirow{3}{*}{ Gender } & Male & \\
\cline { 2 - 3 } & Female & \\
\hline \multirow{3}{*}{ Age Group } & $18-20$ & \\
\cline { 2 - 3 } & $21-23$ & \\
\cline { 2 - 3 } & $24-26$ & \\
\hline \multirow{2}{*}{ Education Level } & $27-30$ & \\
\hline & Primary & \\
\hline & Secondary & \\
\hline
\end{tabular}




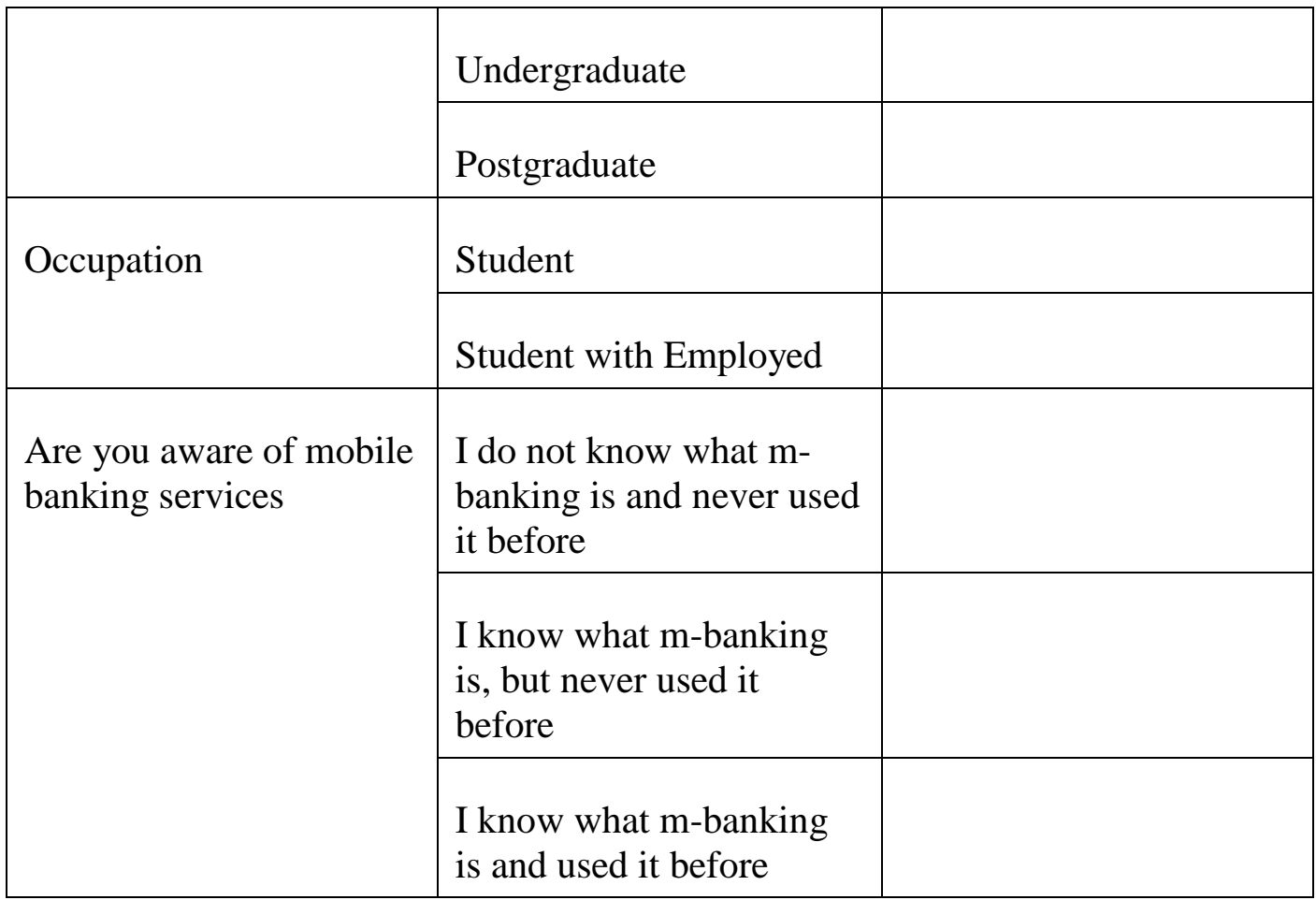

\begin{tabular}{|c|c|c|c|c|c|c|}
\hline \multirow[b]{2}{*}{ CONSTRUCT } & \multirow[b]{2}{*}{ STATEMENTS } & SI & & & & SA \\
\hline & & 1 & 2 & & 4 & 5 \\
\hline \multirow[t]{3}{*}{$\begin{array}{l}\text { Perceived } \\
\text { Usefulness }\end{array}$} & $\begin{array}{l}\text { I think using mobile banking } \\
\text { services would enable me to } \\
\text { save money }\end{array}$ & & & & & \\
\hline & $\begin{array}{l}\text { I think using mobile banking } \\
\text { would make it easier for me to } \\
\text { conduct transactions }\end{array}$ & & & & & \\
\hline & $\begin{array}{l}\text { I would find mobile services } \\
\text { useful in conducting my } \\
\text { transactions }\end{array}$ & & & & & \\
\hline
\end{tabular}




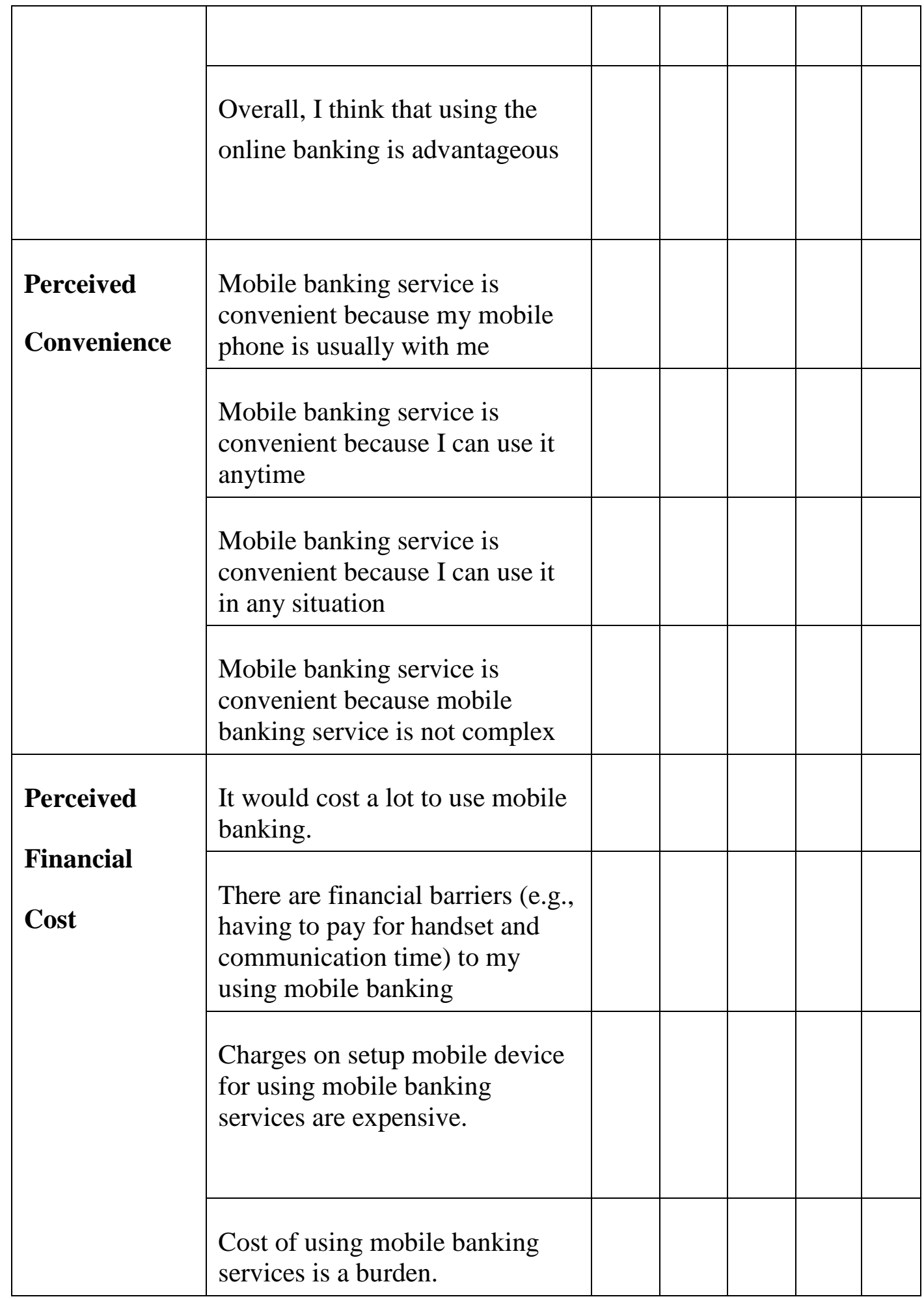




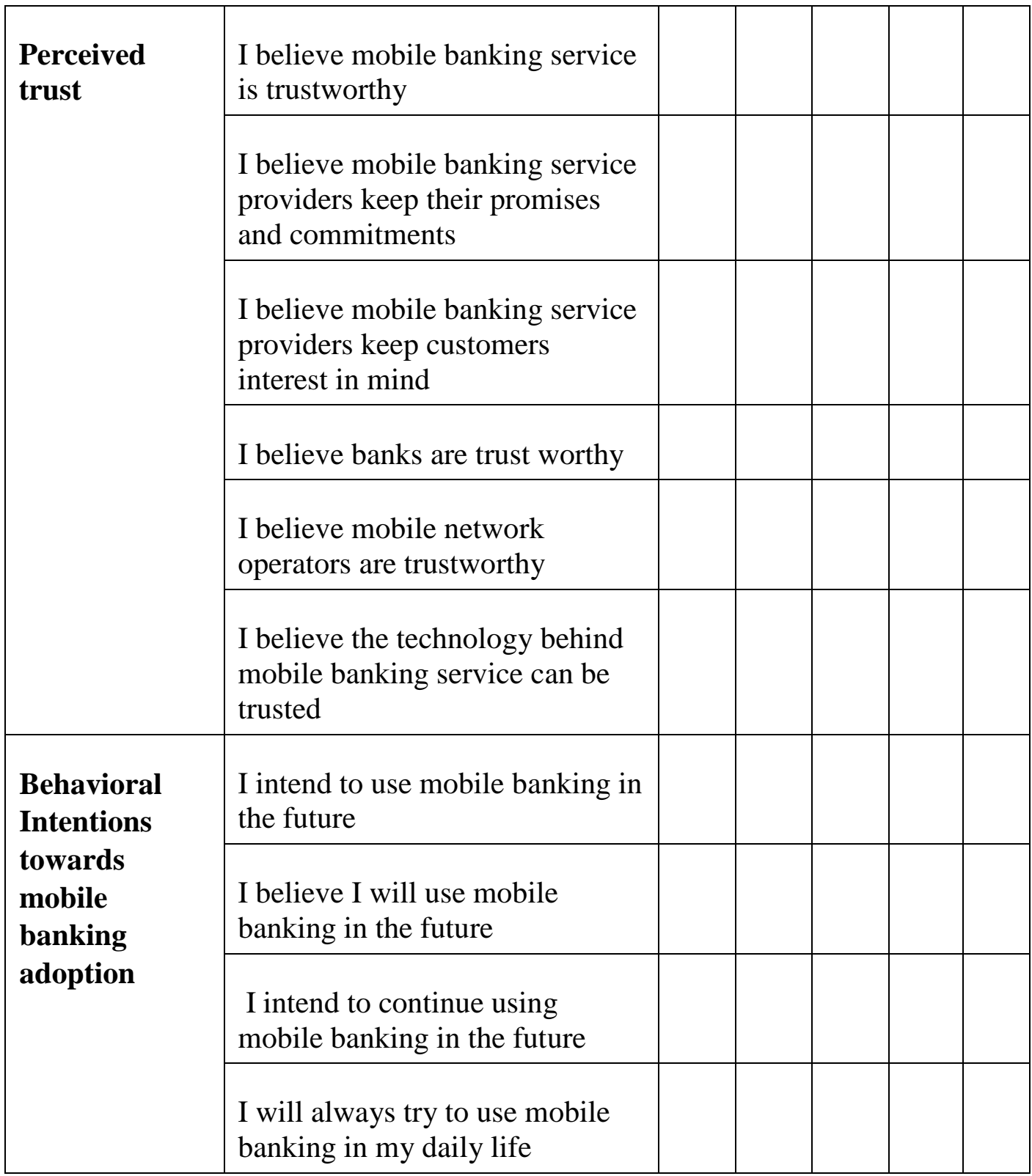

